\title{
Research on Innovation of Ideological and Political Education Mechanism in Colleges and Universities
}

\author{
Siyuan Zhong \\ Liaoning Jianzhu Vocational College, Liaoyang, Liaoning, 111000
}

Keywords: ideological and political education mechanism; colleges and universities, innovation research

\begin{abstract}
The innovation of ideological and political education mechanism in colleges and universities has positive significance. After analyzing the importance of ideological and political education mechanism in colleges and universities, this paper discusses the theoretical basis and practical basis for the innovation of ideological and political education mechanism in colleges and universities. Based on the analysis of the theoretical basis and the realistic basis, it concludes that the innovation of ideological and political education mechanism in colleges and universities is feasible.
\end{abstract}

\section{Introduction}

The ideological and political education mechanism is the intrinsic working method in the process of ideological and political education and the mutual connection of various factors. Only through certain methods can we gradually translate the goals of ideological and political education into the intrinsic needs and motives of educated people, and enable educators to translate this motivation into behavior to obtain good educational effects [1]. Therefore, the education mechanism is also an intermediary and a bridge to achieve educational goals. For a long time, the ideological and political education in Colleges has paid more attention to the construction of goals, contents, and methods. The lack of research on the internal operating mechanisms of ideological and political education has affected the effectiveness of ideological and political education.

\section{The Status and Role of Ideological and Political Education Mechanism in Ideological and Political Education Activities}

The ideological and political education mechanism is a bridge to integrate educational goals, content, methods and approaches, and is an important guarantee for achieving educational results. First, the process of establishing the objectives, content, methods, and approaches of education is an intrinsic work style of ideological and political education. It requires all educators and institutions to follow the laws of ideological and political education and to scientifically grasp the actual basis of the ideology of educators [2]. In the past, the process of research and planning was carried out in accordance with the requirements of society for talents. This process is not only a matter of the ideological and political work team, it involves the overall situation of educational activities. The intrinsic work style has a direct impact on the scientific nature of the goals of ideological and political education and the effectiveness of educational effectiveness. Second, the integration of the goals, contents, methods, and approaches of ideological and political education can only be achieved through ideological and political education mechanisms. According to the educational goals, the content of education is selected, and the methods and methods of content selection are not arbitrary processes. Only through a certain ideological and political education mechanism can we ensure the scientificity and effectiveness of education. The ideological and political education mechanism is the guarantee for solving the basic contradictions of ideological and political education. The contradiction between the ideological and moral requirements of a given society and the ideological and moral levels of educated people that educators possess is a basic contradiction in ideological and political education. It runs through ideological and political education activities. 
Grasping the ideological and moral requirements of society, especially grasping the ideological and political education of educated people is a difficult issue of ideological and political education. To solve this problem, we must rely on certain ideological and educational mechanisms to ensure that we are able to do so. Therefore, we must address the basic contradictions of ideological and political education. In terms of all aspects, we must fully innovate the ideological and political education mechanism in order to receive effective results and achieve the purpose of quality education [3]. Traditional ideological and political education activities only focus on social requirements for the ideological and moral character of college students and ignore the ideological reality of educated people. Educational activities mainly emphasize the role of educators in emphasizing the needs of society, and do not attach importance to the individuality of educators. Seriously affect the effectiveness of ideological and political education. The ideological and political education mechanism is an objective requirement that embodies the basic laws of ideological and political education. Educational activities must be suitable for the ideological and moral status of educated people. This is the basic law of ideological and political education activities, and also the basic basis for ideological and political education mechanism innovation. All educational activities that are not suitable for the ideological status of the educated are essentially meaningless.

To study and grasp the basic laws of ideological and political education, we must first solve the problem of ideological understanding. This basic law reveals the subjective status of educators in ideological and political education activities and provides a theoretical basis for formulating educational goals and selecting educational content and methods. However, in actual education activities, only thoughts and ideas are not enough. There must also be certain mechanisms to ensure that ideological and political education activities are in line with the law. Rethinking the course of ideological and political education activities of university students in China, we deeply realize that we are most in need of This is the mechanism.

\section{The Way of Expression of Educational Mechanism in the Process of Ideological and Political Education}

The ideological and political education mechanism is infiltrated in the process of ideological and political education. It is closely linked with educational ideas, content, and methods. Educators follow the ideological and moral requirements of certain societies and the formation and development patterns of the ideological and moral qualities of the educated, exerting a purposeful, planned, and organized education on the educated, and stimulating the educated to generate inner ideological contradictions [4]. The process of forming the ideological and moral qualities expected by a given society is always achieved through certain educational mechanisms. This can be explained from two aspects: First, the elements of the ideological and political education process, and second, the basic aspects of the ideological and political education process. Educators, educators, educational mediators, and educational rings are the four basic elements of the ideological and political education process. They are interconnected and interact to form a complex ideological and political process. Here, the four elements of "interrelationship" and "interaction" are the mechanisms of ideological and political education. Only through certain internal working methods of ideological and political education can the elements of the education process be organically integrated. In the complex interrelationship of the four elements, the relationship between the educator and the educated person is the core and the key to the contradiction. The bilateral activities of teachers and students through the role of the educational mediator and the impact of the educational system make the educated person's thinking and There has been some change in behavior. The mechanism of ideological and political education is concerned with the respective positions and relationships between educators, educators, educational mediators, and educational rings. The educator is the leading and the educated is the subject. The subject's ideological reality and social needs are the basic basis for formulating educational goals, selecting educational content, methods, and approaches. The mechanisms in the ideological and political education activities are embodied in three aspects: First, educators must formulate and adjust 
educational goals in accordance with certain social needs and the students' actual thinking. In this dynamic process, grasping the development and changes of the society and students' ideological dynamics are the prerequisites and conditions for education and teaching activities. They are the common concerns of university administrators, teachers, and service personnel. Only through certain systems and corresponding mechanisms can Ensure the formulation and implementation of goals. Second, the dynamic nature of the goal determines the dynamics of the contents and methods of ideological and political education. The reform of educational content and methods is not a process that is arbitrary. It is based on the laws of ideological and political education, organized and planned for in-depth research. The procedures and working methods of this process must have systems and corresponding machine production guarantees. Third, ideological and political education activities are the result of a combination of multiple approaches, including theoretical classroom teaching, second classroom activities, social surveys, and practical activities. Selecting the ideological education approach according to certain educational objectives and content is the process in which all educators participate together. Purpose and planning are the main features of this process. Only when certain norms and mechanisms are formed can the effectiveness of ideological and political education be guaranteed.

\section{The Realistic Basis for the Innovation of Ideological and Political Education Mechanism in Colleges and Universities}

In recent years, Colleges have increasingly attached importance to ideological and political education, attached great importance to cultivating outstanding builders and successors in the socialist cause, and constantly improved the ideological and political education mechanism in Colleges, and have achieved remarkable results. With the rapid development of market economy, the current ideological and political education mechanism has been unable to meet the needs of ideological and political education in universities. Therefore, we must innovate the ideological and political education mechanism. The achievements of past ideological and political education mechanisms have provided a realistic basis for this [5].

The Communist Party organization undertook ideological and political responsibilities and led ideological and political education for university students. It initially formed a management mechanism for ideological and political education. The school party committee gave priority to the issue of how to train undergraduate students and how to carry out ideological and political education for college students and provide theoretical guidance. We should make scientific plans, strengthen the building of ideological and political education teams and standardize the system, and at the same time improve and coordinate development.

In the report of the 18th National Congress of the Communist Party of China, education was emphasized: Priority should be given to education in social development. Human resources and power education is the cornerstone of national rejuvenation and education development. Education is an important foundation for social development. It is necessary to fully implement the party's education policy and adhere to the people-oriented principle. The education always takes education as a priority, vigorously implements quality education, raises the level of modern education, fosters the builders and successors of all-round development of morality, intelligence, beauty, and beauty, and realizes citizens' satisfaction with education. Improve the overall quality of the teaching staff, especially the quality of rural teachers. Actively encourage and standardize social forces to start education.

At present, some Colleges have comprehensively established assessment mechanisms that combine student evaluation with teaching supervision. Schools should also combine the evaluation of their work with their individual economic benefits. Through the establishment of a strict assessment system, the school's departments and schools' guiding ideology is to evaluate the educational effectiveness of ideological and political educators as a whole and to put the party's education policy into practice. The real implementation of the ideological and political education to students. Improve the initiative and creativity of ideological and political educators, and clarify the objectives of ideological and political education for college students to ensure that the ideological 
and political education of college students is implemented.

The main approach of ideological and political education in China's universities is based on classroom theory teaching. This is a planned, organized, managed, process, and evaluation system. In addition to this major approach, the activities of the CYL organizations, various community activities, campus cultural activities (referred to as the second class activity), and social practice activities are also important approaches for the ideological and political education of college students. However, the second classroom and social practice activities are in a loose state in the ideological and political education activities in universities. There are vacancy in planning, organization, management, and evaluation. Some of them are only conscious voluntary activities of college students and lack the systematicness and effectiveness of education. The survey found that the daily ideological education in Colleges is out of step with the teaching of public theory courses. The daily ideological education of college students is mostly a simple education on the issue, and sometimes it is managed instead of education, lacking a systematic and rational reasoning. Public theory courses are difficult to achieve due to outdated textbooks, out of touch with social reality and student ideology. The two cannot be organically combined and effectively linked, and they cannot achieve the ideal degree of mutual promotion and mutual benefit.

It can be said that the internal working methods of the ideological and political education process are various and have been fully proved in the practice of ideological and political education in various countries. The choice of mechanism is a dynamic process. There is no permanent model. It is necessary to scientifically and actively select educational mechanisms based on the objective reality of economic and social development and human development, and to achieve institutional innovation in order to ensure the goal of ideological and political education. achieve. However, the choice and innovation of the mechanism are not unfounded and arbitrary processes, but must follow certain principles. First, the mechanism innovation must be based on the principle of solving the basic contradiction of ideological and political education. That is to resolve the contradiction between educational requirements and the educated person's ideological and moral reality. Second, institutional innovation must reflect the basic laws of ideological and political education. The educational activities of educators must be suitable for the regularity of the ideological and moral conditions of educated people. Third, mechanism innovation should reflect the characteristics of the ideological and political education process. Social, practical, versatile, repetitive. Fourth, institutional innovation must be coordinated with and promoted by the innovation of educational ideas, the innovation of educational content, and the innovation of educational methods.

\section{Conclusion}

Establishing a sound and long-term mechanism for ideological and political education plays a very important role in accomplishing the objectives of ideological and political education and achieving the expected results. It is an important aspect that must be considered and indispensable for ideological and political education of college students. Therefore, the mechanism of ideological and political education for undergraduates should be strengthened. Innovation research has important practical significance. On the other hand, the ideological and political education mechanism is a relatively complex and abstract theoretical issue. Since the overall research in this area is still relatively weak, the ideas, viewpoints, and arguments in this article still have many shortcomings and deficiencies. With the continuous development of ideological and political education in Colleges, a series of ideological and political education, especially the study of innovation in education mechanism, will greatly promote the development of ideological and political work in Colleges in order to cultivate a large number of socialist modernized qualified personnel. Make more contributions.

\section{References}

[1] Zheng Ying. A Preliminary Study of the Party Building and Ideological and Political Work in Independent Colleges [J]. National Journal of College of Public Administration, 2005, (5). 
[2] Zheng Jie, Zhang Yan. Exploration of ideological and political education for students in private Colleges [J]. Zhejiang Journal of Jiangshuren University, 2004, (4).

[3] Yang Zhangcheng. Analysis of capital seeking interest and education in private secondary schools The Contradiction of Public Welfare [J]. Journal of Fujian Normal University,2002, (3).

[4] Qi Nuo. Pay attention to strengthening party building, ideological and political work and morality in private universities. Education [J]. Chinese Higher Education Research, 2001, (1).

[5] Yuan Guiren. Effectively strengthen and improve the moral education work in private universities [J]. Thought Theoretical Education Guide, 2004, (4). 